\title{
PENGARUH MODEL PEMBELAJARAN PROBLEM BASED LEARNING (PBL) TERHADAP KEMAMPUAN PEMECAHAN MASALAH MATEMATIKA SISWA KELAS VIII SMP SWASTA HARAPAN PAYA BAKUNG KAB. DELI SERDANG TAHUN PELAJARAN 2017/2018
}

\author{
R. Maisaroh Rezyekiyah Siregar \\ Tika Maulida \\ STKIP Budidaya Binjai \\ maisarohsrg@gmail.com \\ tikamaulida9@gmail.com
}

\begin{abstract}
ABSTRAK
Tujuan penelitian ini adalah untuk mengetahui pengaruh model pembelajaran problem based learning (PBL) terhadap kemampuan pemecahan masalah matematika siswa . Penelitian ini dilakukan di SMP Swasta Harapan Paya Bakung Kabupaten Deli Serdang Tahun Pelajaran 2017/2018. Jenis penelitian ini adalah penelitian Eksperimen Semu dengan desain penelitian Pretest Posttest Control Group Design. Populasi dalam penelitian ini sebanyak 60 siswa. Sampel penelitian ini terdiri dari dua kelas yang diperoleh dengan cara teknik sampel acak yaitu kelas VIII-1 sebanyak 30 siswa sebagai kelas kontrol dan kelas VIII-2 sebanyak 30 siswa sebagai kelas eksperimen. Instrumen yang digunakan dalam penelitian ini adalah tes kemampuan pemecahan masalah matematika siswa yang berbentuk uraian sebanyak 3 soal. Uji prasyarat yang digunakan adalah uji Liliefors untuk menguji normalitas data, sedangkan uji Fisher untuk menguji homogenitas data. Berdasarkan hasil uji normalitas diperoleh bahwa kedua populasi berdistribusi normal. Sedangkan hasil uji homogenitas diperoleh bahwa kedua populasi homogen(sama). Hasil validitas uji coba tes kemampuan pemecahan masalah matematika siswa dinyatakan valid dengan kriteria validitas tinggi sedangkan hasil uji reliabilitas tes memiliki reliabilitas tinggi. Teknik analisis data yang digunakan dalam penelitian ini adalah analisis regresi sederhana. Berdasarkan perhitungan analisis regresi linier sederhana menunjukkan $r_{\text {hitung }}$ 0,84 dan $r_{\text {tabel }} 0,361$ pada taraf signifikan 5\% yang berarti $r_{\text {hitung }}>r_{\text {tabel }}(0,84>0,361)$, maka $H_{0}$ ditolak dan $H_{\mathrm{a}}$ diterima. Sehingga dapat diambil kesimpulan model pembelajaran pembelajaran problem based learning (PBL) berpengaruh terhadap kemampuan pemecahan masalah matematika siswa

Kata Kunci : model pembelajaran problem based learning (PBL), kemampuan pemecahan masalah matematika

\section{PENDAHULUAN}

Pendidikan merupakan suatu proses yang sangat dibutuhkan oleh setiap manusia, selain itu, pendidikan juga memiliki peranan penting dalam menata kehidupan manusia untuk menjadi suatu pribadi yang jauh lebih baik. Hai ini sesuai dengan Undang-Undang
\end{abstract}


Republik Indonesia No.2 Tahun 2003 tentang Sistem Pendidikan Nasional Pasal 1 ayat 1 yang menyatakan bahwa:

"Pendidikan adalah usaha sadar dan terencana untuk mewujudkan suasana belajar dan proses pembelajaran agar peserta didik secara aktif mengembangkan potensi dirinya untuk memiliki kekuatan spiritual keagamaan, pengendalian diri, kepribadian, kecerdasan, akhlak mulia serta ketrampilan yang diperlukan dirinya, masyarakat, bangsa dan Negara".

Undang-Undang tersebut menyatakan bahwa tujuan pendidikan adalah untuk mengembangkan potensi peserta didik agar menjadi manusia yang beriman dan bertakwa kepada Tuhan Yang Maha Esa, berakhlak mulia, sehat, berilmu, cakap, kreatif, mandiri. Dalam pendidikan di Indonesia, salah satu mata pelajaran yang diajarkan disekolah adalah pendidikan matematika.

Pendidikan matematika adalah ilmu yang membahas pola atau keteraturan. Karena matematika merupakan ilmu yang universal yang mendasari perkembangan teknologi modern yang mempunyai peran penting dalam berbagai disiplin dan mamajukan daya pikir manusia. Matematika adalah ilmu tentang bilangan-bilangan, hubungan antara bilangan dan oprasional yang diggunakan dalam penyelesaian masalah mengenai bilangan. Pendidikan matematika haruslah sejalan dengan kebutuhan masyarakat yang semakin berkembang. Menurut Sinaga (dalam Yenny Weidawati:2014) mengatakan bahwa : "Matematika merupakan pengetahuan yang esensial sebagai dasar untuk bekerja untuk mendapatkan pekerjaan yang layak karena abad globalisasi, seumur hidup dalam abad globalisasi, karena itu penguasaan tingkat tertentu terhadap matematika diperlukan bagi semua siswa agar kelak dalam hidupnya memungkinkan tiada pekerjaan tanpa matematika".

Sejalan dengan pernyataan di atas, Depdiknas (2016) juga menyatakan bahwa mata pelajaran matematika SD, SMP, SMA dan SMK bertujuan agar siswa memiliki kemampuan sebagai berikut:

1) Memahami konsep matematika, menjelaskan keterkaitan antar konsep dan mengaplikasikan konsep secara luwes, akurat, efisien, dan tepat dalam pemecahan masalah 
2) Menggunakan penalaran pada pola dan sifat, melakukan manipulasi matematika dalam membuat generalisasi, menyusun bukti, atau menjelaskan gagasan dan pernyataan matematika

3) Memecahkan masalah yang meliputi kemampuan memahami masalah, merancang model matematika, menyelesaikan model dan menafsirkan solusi yang diperlukan

4) Mengkomunikasikan gagasan dengan simbol, tabel, diagram atau media lain untuk memperjelas keadaan atau masalah

5) Memiliki sikap menghargai kegunaan matematika dalam kehidupan, yaitu memiliki rasa ingin tahu, perhatian dan minat dalam mempelajari matematika, serta sikap ulet dan percaya diri dalam pemecahan masalah.

Berdasarkan uraian diatas, terlihat bahwa kemampuan memecahkan masalah menjadi tujuan yang penting dalam pembelajaran matematika. Seperti yang diungkapkan oleh Vettleson (dalam Nella:2014)"In the discipline of mathematics, the use of problem solving skills has been extremely important and highly influential. Problem solvingis the foundation of all mathematical and scientific discoveries". Dalam disiplin ilmu matematika penggunaan keterampilan pemecahan masalah mempunyai pengaruh yang sangat penting. Pemecahan masalah merupakan dasar dari seluruh ilmu matematika dan proses menemukan pengetahuan.

Akan tetapi pada kenyataannya siswa masih mengalami kesulitan dalam pemecahan masalah, dikarnakan materi yang diajarkan sedikit atau kurang sekali penekanan matematika dalam konteks kehidupan sehari-hari. Hal ini didukung oleh dari hasil wawancara peneliti dengan salah satu guru bidang studi matematika dikelas VIII SMP Swasta Harapan Paya Bakung pada tanggal 06 maret 2017 yang mengatakan bahwa model pembelajaran yang digunakan adalah model pembelajaran langsung (konvensional) yang hanya didominasi oleh guru, yakni guru sebagai sumber utama pengetahuan, akibatnya tingkat kemampuan pemecahan masalah matematika siswa serta tingkat pemahaman siswa terhadap materi ajar menjadi kurang optimal dan siswa menjadi pasif. Untuk mendukung pernyataan guru tersebut, maka peneliti melakukan penelitian pendahuluan dengan memberikan test. Instrumen penelitian yang digunakan ialah tes kemampuan pemecahan masalah yang berbentuk soal cerita sebagai berikut : "Rhena berbelanja ke sebuah pasar, ia membeli $2 \mathrm{~kg}$ wortel dan $1 \mathrm{~kg}$ kentang, untuk itu ia harus 
membayar sejumlah Rp.12.500 dan di tempat yang sama putri juga membeli $1 \mathrm{~kg}$ wortel dan $3 \mathrm{~kg}$ kentang dengan harga $R p .15 .000$. Berapakah harga setiap $\mathrm{kg}$ wortel dan kentang?

Seperti pada di atas kita ketahui bahwa siswa masih belum mampu menyelesaikan soal pemecahan masalah dalam sebuah cerita, diketahui dari jawaban 35 siswa, terdapat 8 siswa (23\%) yang memiliki kemampuan pemecahan masalah dengan kategori tinggi karena sudah mampu memahami masalah dengan benar, mampu mempresentasikan masalah ke dalam bentuk persamaan dengan benar sehingga proses perhitungan menjadi benar, siswa mampu menerapkan strategi dan memecahkan masalah. Selain itu, terdapat 11 siswa (31\%) yang memiliki kemampuan pemecahan masalah dengan kategori sedang karena sudah mampu memahami masalah dengan benar, mampu mempresentasikan masalah ke dalam bentuk persamaan dengan benar, siswa mampu menerapkan strategi dan memecahkan masalah walaupun masih salah dalam perhitungan. Sementara itu terdapat 16 siswa (46\%) yang memiliki kemampuan pemecahan masalah dengan kategori rendah. Hal tersebut dikarenakan siswa belum mampu memahami masalah dengan benar, ini terlihat dari cara mempresentasikan masalah ke dalam bentuk persamaan dengan kurang tepat sehingga proses perhitungan menjadi tidak tepat. Siswa juga tidak mampu memilih dan menerapkan strategi dalam memecahkan masalah. Berdasarkan hasil pengamatan tersebut dapat disimpulkan bahwa kemampuan pemecahan masalah di kelas VIII SMP Swasta Harapan Paya Bakung masih rendah. hal tersebut dikarenakan kurang menariknya cara pembelajaran yang diterapkan oleh pendidik atau guru.

Kita ketahui bersama bahwa kemampuan pemecahan masalah merupakan suatu usaha sadar yang dilakukan seseorang dalam rangka mencari jawaban atau ide berkenaan dengan tujuan yang ingin dicapai. Menurut Polya (dalam Fatmawati,dkk, 2014), solusi soal pemecahan masalah memuat empat langkah fase penyelesaiannya, yaitu :

1) Memahami masalah.

2) Membuat rencana pemecahan masalah.

3) Melaksanakan rencana pemecahan masalah.

4) Menguji kembali atau verifikasi

Mengingat kemampuan pemecahan masalah matematika siswa masih rendah, maka perlu didukung oleh metode pembelajaran yang tepat, sehingga tujuan pembelajaran dapat 
tercapai. Wakhyudin (2014) mengatakan bahwa salah satu aspek penting dari perecanaan bertumpu pada kemampuan guru untuk mengantisipasi kebutuhan dan materi-materi atau model-model yang dapat membantu para siswa untuk mencapai tujuan pembelajaran.

Salah satu langkah yang dapat digunakan untuk meningkatkan kemampuan pemecahan masalah matematika adalah dengan pemilihan dan penggunaan model pembelajaran yang tepat agar siswa dapat aktif dan memiliki pengetahuan yang optimal. Penggunaan model pembelajaran yang kurang tepat dapat menimbulkan kebosanan, kurang paham terhadap materi ajar dan akhirnya turunnya motivasi siswa untuk belajar. Dengan demikian, diperlukan suatu model pembelajaran yang menyajikan tugas-tugas dalam bentuk masalah karena dengan adanya masalah maka siswa akan berusaha untuk mencari solusinya dengan berbagai ide sehingga kemampuan berfikir siswa benar-benar dioptimalkan melalui proses pemecahan masalah tersebut. Pembelajaran yang sebaiknya digunakan yaitu pembelajaran berkelompok/kooperatif.

Dalam pembelajaran kooperatif, siswa diberi kebebasan untuk mengkontruksikan pengetahuannya, mengkoordinasikan ide-ide yang dimilikinya. Salah satu model pembelajaran kooperatif yang sesuai adalah Model Pembelajaran Problem Based Learning (PBL). Model pembelajaran Problem Based Learning (PBL) adalah salah satu pembelajaran yang berpusat pasa siswa dan guru sebagai fasilitator. Model ini merupakan pendekatan pembelajaran siswa pada masalah autentik (nyata) sehingga siswa dapat menyusun pengetahuannya sendiri, menumbuh kembangkan keterampilan yang tinggi, memandirikan siswa dan meningkatkan kepercayaan dirinya.

Menurut Sanjaya (2010), Problem Based Learning (PBL) merupakan serangkaian aktivitas pembelajaran yang menekankan kepada proses penyelesaian suatu masalah, sehingga siswa akan menjadi aktif dalam berfikir, berkomunikasi, mencari penyelesaian, dan akhirnya menyelesaikannya. Pendapat tersebut dapat diartikan bahwa dalam Problem Based Learning (PBL) peran guru adalah sebagai fasilitator yang merancang sebuah masalah dimana pemecahannya didiskusikan dan diselesaikan secara bersama-sama. Adapun masalah yang diberikan disesuaikan dengan jangkauan pemikiran dan kebutuhan belajar siswa. 


\section{METODE}

Penelitian ini dilaksanakan di SMP Swasta Harapan Paya Bakung, Kab. Deli Serdang. Waktu penelitian pada bulan september dan dilaksanakan pada semester ganjil tahun pelajaran 2017/2018. Populasi dalam penelitian ini adalah seluruh peserta didik Kelas VIII SMP Swasta Harapan Paya Bakung. sebanyak 2 kelas. Dengan rata-rata jumlah murid 30 orang.

Adapun pada penelitian ini pengambilan sampel menggunakan teknik simple random sampling yaitu pengambilan anggota sampel dari populasi dilakukan secara acak tanpa memperhatikan strata yang ada dalam populasi itu (Arikunto,2006). Cara demikian digunakan dalam penelitian ini karena seluruh anggota populasi dianggap homogeny kemampuanya yang dapat mewakili karakteristik populasi dan disesuaikan dengan tujuan yang diinginkan oleh peneliti.

Metode yang di gunakan dalam penelitian ini adalah metode eksperimen semu, karena tidak memungkinkan peneliti mengadakan pengontrolan penuh terhaadap variabel kondisi eksperimen. Sampel penelitian ini akan di kelompokkan menjadi 2 dan diberikan perlakuan pembelajaran kelas eksperimen dalam proses pembelajarannya menggunakan proses pembelajaran Problem Based Learnng (PBL), sedangkan untuk kelas kontrol dalam pembelajarannya menggunakan metode pembelajaran langsung (konvensional).

Desain penelitian yang digunakan dalam penelitian ini adalah Randomize PretestPosttest Control Group Design. Rancangan ini merupakan rancangan penelitian eksperimen yang dilakukan dengan pretest (tes awal) selanjutnya diberi perlakuan dan diakhiri dengan posttest. (tes akhir). Desain ini melibatkan dua kelas, yaitu kelas kelompok eksperimen dan kelas control. Adapun pola dalam desain ini dapat digambarkan sebagai berikut :

\section{Desain Penelitian (Pretest-Posttest Control Group Design}

$$
\begin{array}{cccc}
\mathrm{E} & \mathrm{O}_{1} & \mathrm{X} & \mathrm{O}_{2} \\
\mathrm{~K} & \mathrm{O}_{1} & & \mathrm{O}_{2}
\end{array}
$$

Instrumen yang digunakan untuk mengumpulkan data adalah tes berbentuk uraian dengan tujuan untuk mengetahui kemampuan pemecahan masalah matematika siswa pada pokok bahasan sistem persamaan linier dua variabel (SPLDV). Tes yang digunakan 
disusun sesuai dengan kurikulum yang berlaku. Tes diberikan setelah pembelajaran dilaksanakan. Tes ini bertujuan untuk mengukur penguasaan kemampuan pemecahan masalah matematika siswa terhadap materi yang diajarkan oleh guru setelah siswa memperoleh sejumlah materi

Sebelum tes diberikan kepada kelas sampel, dilakukan uji coba soal tes untuk mengetahui soal layak digunakan atau tidak. Ketentuannya ialah apabila suatu tes dijawab dengan benar maka peserta didik memperoleh nilai 1 dan bila dijawab salah maka bernilai 0 .

Untuk menguji kelayakan tes maka sebelum digunakan sebagai alat pengumpul data, terlebih dahulu di validasi oleh empat validator dimana validator merupakan dua dosen matematika STKIP Budidaya Binjai dan dua guru mata pelajaran matematika. Selanjutnya tes di uji cobakan dan di analisa validitas, reliabilitas, tingkat kesukaran dan daya pembeda. Hasil validitas butir soal dapat dilihat pada di bawah ini.

\section{Validitas Butir Soal}

\begin{tabular}{|c|c|c|c|}
\hline Soal & $\mathbf{r}_{\text {hitung }}$ & $\mathbf{r}_{\text {tabel }}$ & Ket \\
\hline 1 & 0,518 & 0,361 & Valid \\
\hline 2 & 0,525 & 0,361 & Valid \\
\hline 3 & 0,842 & 0,361 & Valid \\
\hline
\end{tabular}

Jika kita merujuk pada kriteria pengujian "Jika $r_{\text {hitung }}>r_{\text {tabel }}$ maka soal dikatakan valid", maka keseluruhan item soal pretest dapat digunakan untuk mengukur kemampuan pemecahan masalah matematika siswa pada pokok bahasan sistem persamaan linear dua variabel ditinjau dari validitas tes.

\section{Reliabilitas Butir Soal}

\begin{tabular}{|c|c|c|c|c|}
\hline No & Tes & $\mathbf{r}_{\mathbf{1 1}}$ & $\mathbf{r}_{\text {tabel }}$ & Ket \\
\hline 1 & pretest & 0,92 & 0,361 & tinggi \\
\hline 2 & posttes & 0,435 & 0,361 & Cukup \\
\hline
\end{tabular}

Dilihat dari kriteria reliabilitas, hasil reliabilitas uji coba tes kemampuan pemecahan masalah matematika pretest dan posttest berada pada kriterian $0,40<\mathrm{r} \leq 0,70$ dan $0,90<\mathrm{r} \leq 1,00$ yang artinya soal memiliki reliabilitas sangat tinggi dan cukup. 


\section{Kesukaran Butir Soal}

\begin{tabular}{|c|c|c|}
\hline Soal & Kesukaran & Ket \\
\hline 1 & 0,52 & Sedang \\
\hline 2 & 0,51 & Sedang \\
\hline 3 & 0,32 & Sedang \\
\hline
\end{tabular}

Jika merujuk pada klasifikasi indeks kesukaran, rata-rata soal uji coba tes kemampuan pemecahan masalah matematika posttes berada pada indeks $0,30<\mathrm{P} \leq 0,70$. Hal ini berarti soal memiliki taraf kesukaran sedang dan sukar.

\section{Daya Beda Butir Soal}

\begin{tabular}{|c|c|c|}
\hline Soal & $\begin{array}{c}\text { Daya } \\
\text { Pembeda }\end{array}$ & Keterangan \\
\hline 1 & 0,27 & Cukup \\
\hline 2 & 0,25 & Cukup \\
\hline 3 & 0,20 & Cukup \\
\hline
\end{tabular}

Dari hasil uji coba daya pembeda tes kemampuan pemecahan masalah matematika posttest diperoleh hasil uji coba daya pembeda, rata-rata berada pada kriterian yang sama. Hal ini berarti uji coba daya pembeda tes kemampuan pemecahan masalah matematika posttest dapat cukup.

\section{HASIL DAN PEMBAHASAN PENELITIAN}

Berdasarkan penelitian yang telah dilakukan, diperoleh data kemampuan pemecahan masalah matematika siswa. Data yang diperoleh antara lain data hasil pretest dan posstest siswa.

Data Pretest Kelas Eksperimen dan Kelas Kontrol

\begin{tabular}{|c|c|c|c|}
\hline No & Statistik & $\begin{array}{c}\text { Kelas } \\
\text { Eksperimen }\end{array}$ & $\begin{array}{c}\text { Kelas } \\
\text { Kontrol }\end{array}$ \\
\hline 1 & N & 30 & 30 \\
\hline 2 & $\begin{array}{c}\text { Rata- } \\
\text { rata }\end{array}$ & 6,7 & 5,8 \\
\hline 3 & S. Baku & 2,3 & 2,1 \\
\hline
\end{tabular}

Pada tabel di atas terlihat bahwa nilai rata-rata dikelas eksperimen 6,7 dan pada kelas kontrol diperoleh nilai rata-rata 5,8. Dari hasil perhitungan pretest pada kelas eksperimen diperoleh simpangan baku 2.3. Sedangkan pada kelas kontrol diperoleh nilai 
simpangan bakunya yaitu 2.1. Data Pretest Kelas Eksperimen dan Kelas Kontrol juga dapat dilihat pada histogram berikut.

Data Uji Normalitas

\begin{tabular}{|c|c|c|c|c|}
\hline \multirow{2}{*}{ Kelas } & \multicolumn{2}{|c|}{$\mathbf{L}_{\text {hitung }}$} & \multirow{2}{*}{$\mathbf{L}_{\text {tab }}$} & \multirow{2}{*}{ Kes } \\
\cline { 2 - 4 } & $\begin{array}{c}\text { Pre } \\
\boldsymbol{e}\end{array}$ & $\begin{array}{c}\text { Pos } \\
\boldsymbol{t}\end{array}$ & el & \\
\hline \multirow{2}{*}{ Eks } & 0,1 & 0,2 & 0,1 & Terim \\
& 3 & 3 & 6 & $\mathrm{a} \mathrm{H}_{0}$ \\
\hline Kontro & 0,1 & 0,2 & 0,1 & Terim \\
1 & 5 & 1 & 6 & $\mathrm{a} \mathrm{H}_{0}$ \\
\hline
\end{tabular}

Pada tabel di atas dapat disimpulkan bahwa uji normalitas bersifat normal.

\section{Data Uji Homogenitas}

\begin{tabular}{|c|c|c|c|}
\hline Data & $\begin{array}{c}\text { Kelompo } \\
\mathbf{k}\end{array}$ & $\mathbf{F}_{\text {hitung }}$ & $\mathbf{F}_{\text {tabel }}$ \\
\hline $\begin{array}{c}\text { Prete } \\
\text { st }\end{array}$ & $\begin{array}{c}\text { Eksperime } \\
\mathrm{n}\end{array}$ & 1,20 & 1,86 \\
\hline $\begin{array}{c}\text { Poste } \\
\text { st }\end{array}$ & Kontrol & 1,005 & 1,86 \\
\hline
\end{tabular}

Setelah dilakukan pengujian prasyarat analisis data, diketahui bahwa data tersebut berdistribusi normal dan homogen, selanjutnya dilakukan pengujian hipotesis statistik dengan mengunakan uji regresi sederhana yang dilajutkan dengan uji korelasi product moment.

Adapun analisis regresi digunakan untuk memprediksi seberapa jauh perubahan nilai variabel terikat, bila nilai variabel bebas dimanipulasi atau dirubah-rubah. Dari hasil perhitungan yang telah dilakukan pada akhirnya didapatkan persamaan regresi. Persamaan regresi yang dimaksud adalah persamaan regresi pada kelas eksperimen, persamaan regresi yang didapat adalah: $\bar{Y}=1,99+0,85 \mathrm{X}$. Dimana $\hat{\mathrm{Y}}=$ taksiran nilai posttest dan $\mathrm{X}=$ nilai prettest.

\section{Uji Keberartian Regresi}

\begin{tabular}{|c|c|c|c|c|}
\hline $\begin{array}{c}\text { Varia } \\
\text { ns }\end{array}$ & $\begin{array}{l}\text { D } \\
\text { K }\end{array}$ & JK & $\begin{array}{c}\text { RJ } \\
\mathbf{K}\end{array}$ & $\mathbf{F}$ \\
\hline $\begin{array}{l}\text { Reg } \\
\text { (a) }\end{array}$ & 1 & $\begin{array}{c}1.373 \\
, 63\end{array}$ & - & $\begin{array}{c}\mathrm{F}_{\text {hitun }} \\
\mathrm{g}= \\
67.5 \\
34\end{array}$ \\
\hline $\begin{array}{l}\text { Reg } \\
\text { (b/a) }\end{array}$ & 1 & $\begin{array}{c}118.3 \\
2\end{array}$ & $\begin{array}{c}118 . \\
32\end{array}$ & \\
\hline
\end{tabular}




\begin{tabular}{|l|c|c|c|c|}
\hline $\begin{array}{l}\text { Resid } \\
\mathbf{u}\end{array}$ & 28 & 49,05 & $\begin{array}{c}1.75 \\
2\end{array}$ & \\
\hline Total & $\mathbf{3 0}$ & $\begin{array}{c}\mathbf{1 8 4 . 3} \\
\mathbf{1 5}\end{array}$ & $\begin{array}{c}\mathbf{6 4 2} \\
\mathbf{2}\end{array}$ & \\
\hline
\end{tabular}

Dari tabel distribusi $F$ diperoleh $F_{\text {tabel }}$ dengan $d_{b}$ pembilang $=1$ dan $d_{b}$ penyebut $=N$ $-2=30-2=28$ pada taraf $\alpha=0,05$ makaF $_{\text {tabel }}=\mathrm{F}_{0,05(1,28)}=4,20$. Dengan demikian dapat dilihat bahwa $\mathrm{F}_{\text {hitung }}>\mathrm{F}_{\text {tabe }}$ yaitu 67,53>4,20 maka $\mathrm{h}_{0}$ di tolak dan dapat disimpulkan bahwa koefisien arah persamaan regresi cukup berarti.

\section{Analisis Uji Keberartian}

\begin{tabular}{|c|c|c|c|c|}
\hline $\begin{array}{c}\text { Sumbe } \\
\mathbf{r} \\
\text { Varian } \\
\text { s }\end{array}$ & $\begin{array}{l}\mathbf{D} \\
\mathbf{K}\end{array}$ & JK & RJK & $\mathbf{F}$ \\
\hline $\begin{array}{l}\text { Tuna } \\
\text { Cocok }\end{array}$ & 3 & $\begin{array}{c}119, \\
95\end{array}$ & $\begin{array}{c}39,9 \\
8\end{array}$ & $\begin{array}{c}F_{\text {hitung }} \\
= \\
5,91\end{array}$ \\
\hline $\begin{array}{l}\text { Kekelir } \\
\text { uan }\end{array}$ & $\begin{array}{l}2 \\
5\end{array}$ & 169 & 6,76 & \\
\hline Total & $\begin{array}{l}2 \\
8\end{array}$ & $\begin{array}{c}288, \\
95\end{array}$ & $\begin{array}{c}47,7 \\
4\end{array}$ & \\
\hline
\end{tabular}

Dengan melihat daftar distribusi $F$ dengan $d_{b}$ pembilang $=\mathrm{N}-\mathrm{K}=30-5=25$ dan $\mathrm{d}_{\mathrm{b}}$ penyebut $=\mathrm{K}-2=3$ pada taraf $\alpha=0,05$ makaF$_{\text {tabel }}=\mathrm{F}_{0,05}(23,5)=2,64$. Dengan demikian dapat dilihat bahwa $F_{\text {hitung }}>F_{\text {tabel }}$ yaitu 5,91 > 2,64 berarti Ho diterima sehingga dapat disimpulkan bahwa persamaan regresi $\hat{Y}=1,99+0,85 \mathrm{X}$ adalah linier.

\section{Uji Hipotesis}

\begin{tabular}{|c|c|c|c|}
\hline$\underset{g}{\mathbf{r}_{\text {hitun }}}$ & $\mathbf{r}_{\text {tabe }}$ & $\mathbf{N}$ & Hipotesis \\
\hline 0,84 & $\begin{array}{l}0,3 \\
6\end{array}$ & $\begin{array}{l}3 \\
0\end{array}$ & $\begin{array}{l}\mathrm{r}_{\text {hitung }}>\mathrm{r}_{\text {tabel }} \text { maka } \\
\text { Ho ditolak dan } \\
\text { Ha diterima }\end{array}$ \\
\hline
\end{tabular}

Dari tabel di atas menunjukkan hasil perhitungan dengan menggunakan regresi, maka diperoleh $r_{\text {hitung }}=0,84$. Kemudian nilai tersebut dibandingkan dengan $r_{\text {tabel }}=0,36$ dengan $\mathrm{n}=30-2=28$ dan taraf signifikan 5\%. Karena $\mathrm{r}_{\text {hitung }}>\mathrm{r}_{\text {tabel }}$ maka Ho ditolak dan Ha diterima, dengan demikian dapat disimpulkan bahwa terdapat pengaruh pembelajaran problem based lerning (PBL) terhadap kemampuan pemecahan masalah matematika siswa. 


\section{SIMPULAN}

Berdasarkan hipotesis yang diajukan sebelumnya dan setelah dilakukan penelitian pada siswa kelas VIII SMP Swasta Harapan, penelitian dilakukan pada dua kelas yang berbeda, di mana kelas VIII-1 diberikan perlakuan yang berbeda dengan kelas VIII-2. Untuk kelas VIII-1 pembelajaran dilaksanakan menggunakan model pembelajaran problem based learning (PBL), sedangkan untuk kelas VIII-2 pembelajaran dilaksanakan dengan menerapkan model pembelajaran konvensional. Peningkatan dapat dilihat dari perbandingan nilai rata-rata posttest.

Kemampuan pemecahan masalah matematika siswa kelas eksperimen dan kelas kontrol dan serta hasil uji r yang dilakukan terhadap nilai posttest eksperimen. Nilai ratarata posttest kelas eksperimen sebesar 6,7. Nilai ratarata posttest kelas kontrol sebesar 5,8. Hasil penghitungan uji hipotesis didapatkan $r_{\text {hitung }}=0,84$, sedangkan nilai $r_{\text {tabel }}=0,36$ pada taraf signifikansi $\alpha=0,05$. Berdasarkan nilai tersebut maka diketahui nilai $r_{\text {hitung }}>r_{\text {tabel }}$ $(0,84>0,36)$. Dengan demikian dapat disimpulkan bahwa terdapat pengaruh model pembelajaran problem based learning (PBL) terhadap kemampuan pemecahan masalah matematika siswa.

\section{REFERENSI}

Arikunto, Suharsimi. Prosedur Penelitian. Jakarta : Rineka Cipta. 2006

Depdiknas. Standart Isi Untuk Satuan Pendidikan Dasar dan Menengah. Jakarta: Direktorat Badan Standart Nasional Pendidikan. 2016

Fatmawati, Harlida, dkk. Analisis Berfikir Kritis Siswa Dalam Pemecahan Masalah Matematika Elektronik

Berdasarkan Polya Pada Pokok Bahasan Persamaan Kuadrat. Sragen : Jurnal Pembelajaran Matematika, Volume 2, No.9, 2014

Meidawati, Yenny. Pengaruh Pembelajaran Inkuiri Terbimbing Terhadap Penigkatan Kemampuan Pemecahan Masalah Matematika Siswa SMP. Tanggamus : Jurnal Pendidikan dan Keguruan, Volume 1, No. 2, 2014

Nella, Eka. Perbandingan Pembelajaran Konvensional dan Pembelajaran Berbasis Masalah Terhadap Titik Jenuh Siswa Maupun Hasil Belajar Siswa. Jurnal Pendidikan Matematika, Volume 1, 2014 
Jurnal Serunai Matematika

Vol.10, No.2, Agustus 2018

e-ISSN 2620-9217

Sanjaya, Wina. Strategi Pembelajaran Berorientasi Standart Proses Pendidikan. Jakarta : Kencana, 2010

Undang-Undang Republik Indonesia. Tentang Sistem pendidikan Nasional. No.2, Tahun 2003

Wakhyudin, Husni, dkk. Model Pembelajaran Heads Together Terhadap Kemampuan Pemecahan Masalah Siswa Kelas IV. Jepara : Volume 4, No. 2, 2014 